JOURNAL OF SECURITY AND SUSTAINABILITY ISSUES

ISSN 2029-7017 print/ISSN 2029-7025 online

2021 Volume 11

https://doi.org/10.47459/jssi.2021.11.36

\title{
INFORMATION AS AN ELEMENT OF SECURITY IN THE PENITENTIARY UNIT (BASED ON POLISH SOLUTIONS)
}

\author{
Jakub Werbiński
}

Academy of Justice, 50 Wiśniowa Street, 02-520 Warsaw, Poland

E-mail: jakub.werbinski@swws.edu.pl

Received 27 February 2021; accepted 15 May 2021; published 30 June 2021

\begin{abstract}
In the study presented here, the author attempts to answer questions about the acquisition of information by prison staff that may have a bearing on their safety related to their service and work, the safety of isolated persons, and the general public. Internal regulations of the Prison Service (PS) related to the process of obtaining, processing, collecting and using information are indicated and discussed. Based on the research, the knowledge and action of PS officers in this area was analysed. The article aims to show information as an important factor directly affecting the security of penitentiary units.
\end{abstract}

Key words: security of the penitentiary unit; prevention activities; information; prison; detention centre

Reference to this paper should be made as follows: Werbiński, J. 2021. Information as an element of security in the penitentiary unit (based on Polish solutions). Journal of Security and Sustainability Issues, 11, 401-410. https://doi.org/10.47459/jssi.2021.11.36

JEL Classifications: K39, Z00

Additional disciplines: Security Sciences

\section{Introduction}

The Prison Service influences the level of structural and personnel security, which is embedded in several pillars. One of them is information. The changing reality poses new challenges to the formation and means that the solutions developed in this area require constant monitoring. New threats that may emerge should already today mobilise us to look for solutions on how to obtain information in the future and how to make the best use of it. Obtaining this information and processing it correctly enables making decisions that allow anticipatory action to be taken, thus minimising or eliminating risks. Acquiring information and using it for security purposes in Poland is the responsibility of tens of thousands of Prison Service officers and employees, who work in 120 prisons and remand centres, and protect the whole of society from criminals. These activities in places like prisons, and the specificity of the population in relation to which they are carried out - the inmates - acquire uniqueness that the author will demonstrate below.

Prison Service is one of the institutions of the state to provide conditions for its proper functioning. Above all, it takes responsibility for isolating people from society through the execution of prison sentences and pre-trial detention. It is also entrusted with other tasks such as conducting penitentiary and rehabilitation activities, ensuring appropriate conditions for serving sentences or ensuring order and security in prisons. Of course, the majority of tasks are carried out, as in the past, within penitentiary units (Lewandowski, 2019), but new ones are emerging which require activities to be undertaken in the open environment and greater cooperation with external entities. 
For the purposes of these very important, albeit fundamental tasks, the formation undertakes multifaceted actions, whose common denominator is ensuring structural and personal security in the broad sense of the term. In these activities, information retrieval should be identified as an important element of the overall systemic protection architecture.

The importance of information in the modern world does not need to be proven (Lidel, Piasecka \& Aleksandrowicz, 2012). Our functioning - whether at the level of the individual or the local community, the state or supranational structures - requires the use of a great deal of information. This is by no means a specific feature of modern times, but the development of modern information technologies has brought about far-reaching changes precisely related to the use of information, access to it, its processing and its use.

In the most general terms, information is data in various forms (numbers, sound, text, etc.) that increases our knowledge of a subject (Information - definition, stages of information preparation, n. d.). Information can be considered in many dimensions, depending on which the term takes on a different meaning. It is a phrase of great versatility and use, ranging from colloquial language to highly professional and precise terminology. In penitentiary units, too, this particular type of obtained information has acquired its own institutional colouring. And information itself can be a determinant of decisions and actions.

\section{Information and security of the penitentiary unit.}

Information, and especially its acquisition, is a continuous process. A similar situation exists in all prisons and detention centres, where obtaining information relevant to the security of these units is an extremely important element of the entire security system (Figure 1).

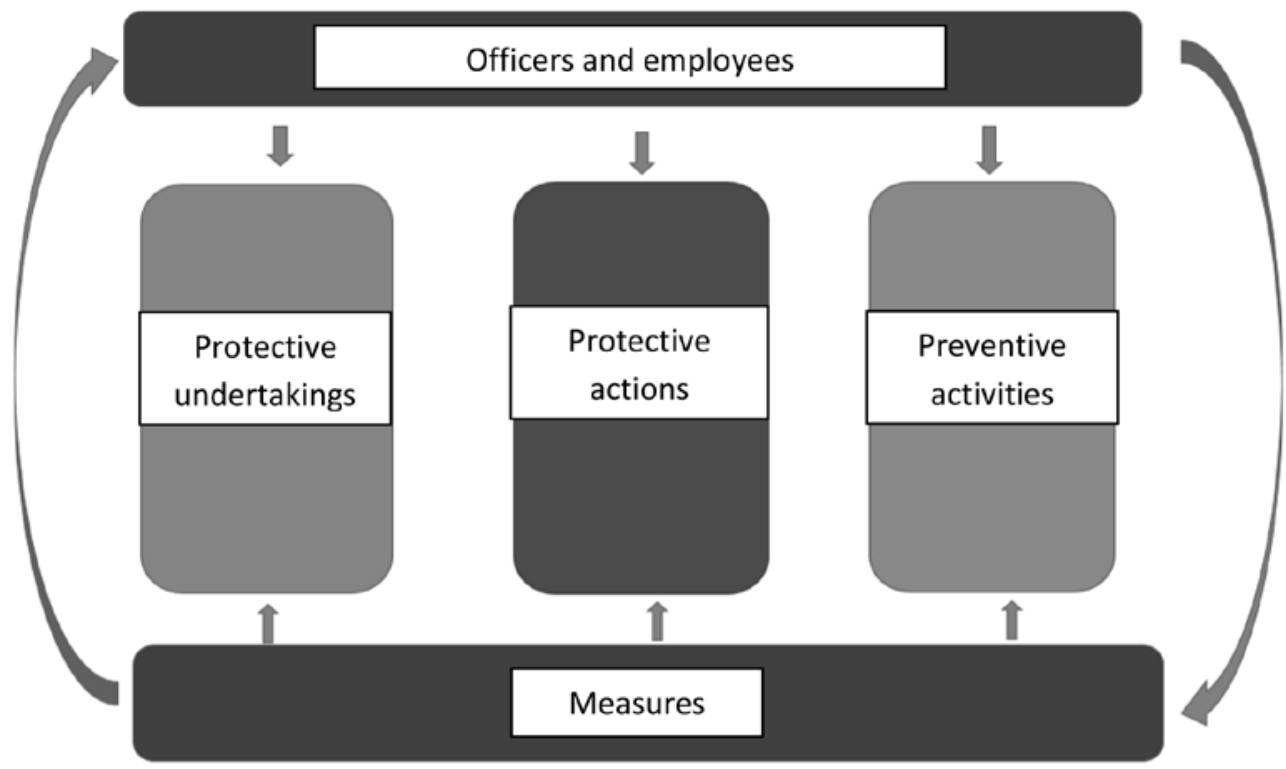

Figure 1. Elements of the manners of protection of a prison / detention centre

Source: Own elaboration.

The Prison Service has been obligated to carry out numerous tasks, which have changed over the years (Bulenda, Rzepliński, 2019). However, some of them are very characteristic of this formation and are undoubtedly related to the acquisition, processing, collection and use of information. Information plays an important role in the implementation of the primary tasks of the Prison Service. The formation has been given statutory powers to process information and personal data necessary for the performance of its tasks. 
The acquisition of information affecting security in penitentiary units is referred to as the implementation of preventive activities. Their implementation is structured and formalised at numerous levels of the Prison Service. Information gathering, due to its not fully measurable nature, very often depends on the involvement of particular individuals. Each prison and detention centre has a specific security arrangement that comprehensively attempts to address the provision of security. One of its basic elements is the acquisition of information (implementation of preventive actions).

In organisational units, officers and employees carry out preventive activities aimed at recognising the environment of inmates and their intentions to undermine order and security (Regulation of the Minister of Justice, 2016, § 33), in particular through:

1) observing behaviours and relationships in the detainees' environment;

2) identifying criminal subculture structures;

3) identifying the atmosphere and mood among the detainees and their intentions to compromise the security of the unit.

Many years of prison practice and the functioning of penitentiary systems show that familiarity with prisoners (Werbiński, 2015) and their environment plays a very important role in preventing security risks in prisons and detention centres (Poklek, 2010). The realisation of this postulate cannot be easily guaranteed by means of legal provisions, but as can be seen from the norms discussed - they can be conducive to it. An important role may also be played by the number of staff supervising the implementation of imprisonment and temporary detention (in Poland there are 2.7 imprisoned persons per one officer or employee) and their preparation (e.g. their knowledge of psychology and sociology). The ratio of officers to detainees in Poland is somewhat lower than in some European countries, and various measures are being taken to eliminate the negative consequences associated with this tendency, also with regard to the issue of obtaining information.

Among the protective tasks of officers and employees of the formations and prison workplaces we find those provided for unit directors. One of them requires the organisation of a system for obtaining information by prison staff. The tasks of the director with regard to the security of the organisational unit (Regulation of the Minister of Justice, 2016, § 1, par. 4) include, in particular: organising the identification of the mood and atmosphere among inmates and their intentions detrimental to order and security.

This involves delegating detailed tasks to subordinate, individual officers and employees, and issuing internal regulations in this respect in the form of orders, instructions or guidelines. As information-gathering staff, one should certainly mention those carrying out tasks in direct contact with prisoners. These are officers and staff of the penitentiary units (Order No. 23/18 of the Director General of the Prison Service, 2018, § 1, par. 5). An example would be the inspector of the security department in the penitentiary unit who coordinates activities related to information relevant to security. However, it must be remembered that all officers and employees, regardless of their place of duty, are obligated to collect and pass on relevant information.

The formation, through years of experience in obtaining information, has developed numerous techniques by which it obtains the desired information. The catalogue of techniques indicated by the author represents a selected part of the possible choices, while they are the most popular and obvious ones in the course of service and work. These include observation, interview, conversation control, documentary analysis or personal sources of information (Figure 2). 


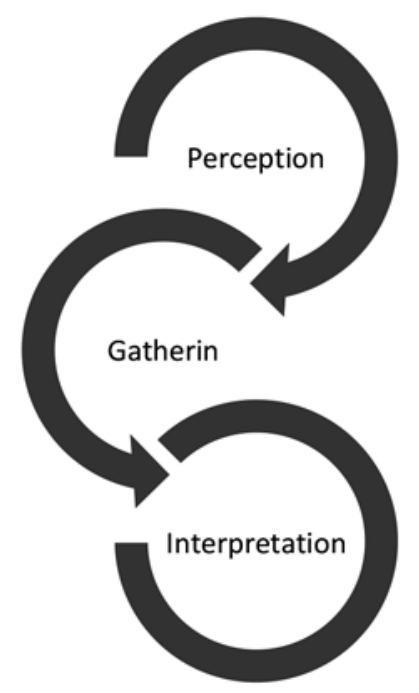

Figure 2. Stages of observation

Source: Czarkowski, J.J., 2019.

\section{Analysis of information and its use}

The acquisition of information in itself is very important. However, what happens with this information is crucial. Acquisition itself should be the catalyst that triggers further action. The systemic solutions adopted in the formation, from central decisions to actions in basic units, lead to an adequate handling of information.

The director of the penitentiary or remand prison determines the principles and manner of collecting, processing and transmitting information obtained as a result of the implementation of preventive activities (Regulation of the Minister of Justice, 2016, §33, par. 2), taking into account, of course, the indications of higher superiors in this regard (Figure 3).

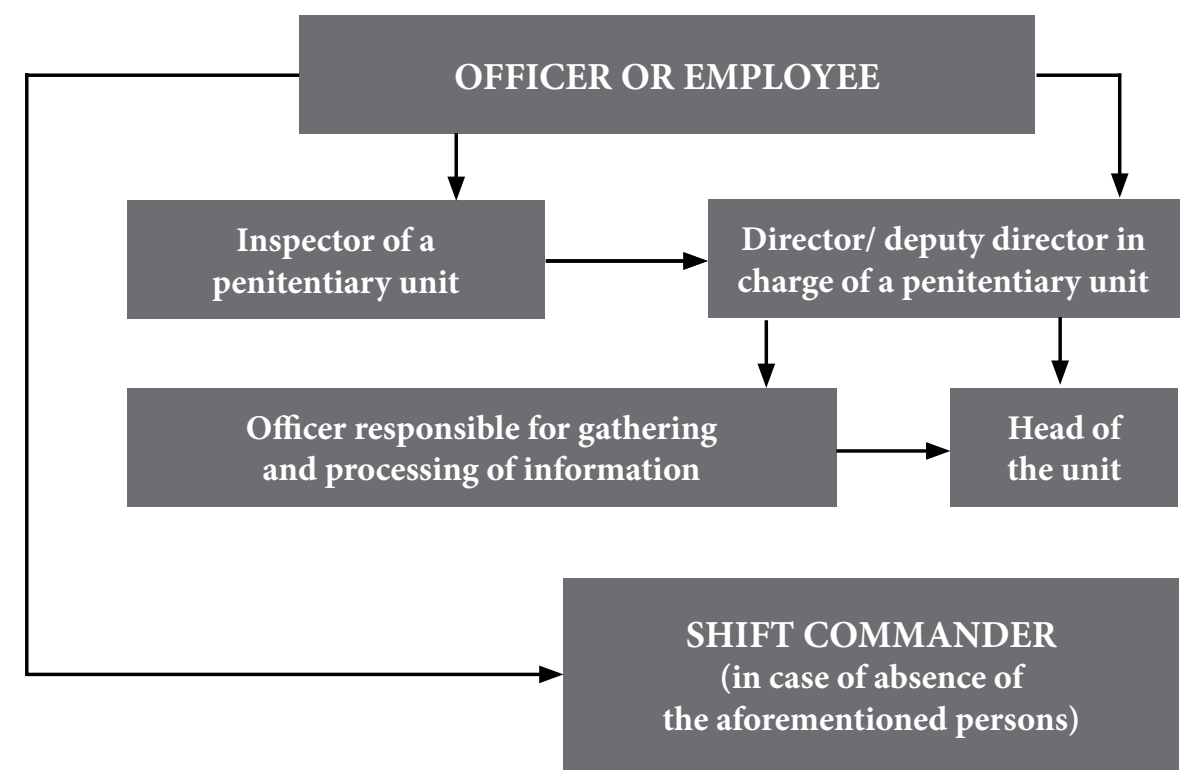

Figure 3. Circulation of information obtained during the implementation of preventive activities concerning the penitentiary unit 
In the penitentiary unit, information, once acquired, is forwarded to the relevant persons or analytical teams. Attempts have been made to standardise the circulation of security-relevant information (also due to its nature). Every officer and employee is expected to respond appropriately once information is received, which is most often just by passing it on to a designated person. A very obvious example is when a prisoner escapes. If the officer has not prevented it themselves, they will certainly pass this information on to the right people. The head of the unit will then take appropriate action, depending certainly on the circumstances and the information available to them (Regulation of the Minister of Justice, 2016, §65, par. 2) they will certainly inform the locally competent police unit and the police unit in the place of residence of the prisoner, as well as organise a pursuit.

The next step is processing information. Processing is the stage of the analytical cycle necessary to produce the final analytical product (Federal Bureau of Investigation, n.d.). It involves giving the collected set of data, often raw (e.g. of a mathematical or statistical nature), and information a form usable by the analyst. This can include decryption, translation, data reduction - and the subsequent introduction of the collected resource into databases where it can be used for analytical purposes.

Information gathering includes both the collection of individual information and raw data. The manner in which information is stored shall be laid down in the unit's internal procedures (Instruction of the Deputy Director General of the Prison Service, 2012). This most often takes the form of business notes. Communicating and collecting information in written form has the advantage of not allowing facts to be distorted. However, there are situations where information is communicated orally. Sometimes this is the most optimal solution, e.g. in situations where response time plays a huge role. The key, however, is for the managers of penitentiary units to make the right decisions to influence reality through their actions and ultimately prevent undesirable phenomena. The use of information is not always easy, as it is not always possible to establish a quantity of facts that would give one hundred per cent certainty of the decision. In many cases, however, making no decision at all can prove even more lamentable.

Deciding is a process that enables not only day-to-day functioning (Lidel, Piasecka \& Aleksandrowicz, 2013), but also growth and survival in the most difficult of conditions. The ability to face challenges, exploit opportunities, eliminate (or at least minimise) threats depends on the right decisions being made. This is why decision analysis and decision-making processes in an organisation are such an important part of managing it under all conditions.

In the case of the Prison Service, it is also important not to encroach on the competences of other services in the course of these activities. A distinction must be made between the gathering of information as part of the implementation of preventive activities and activities envisaged and reserved for law enforcement authorities. The cooperation of the Police and the Penitentiary Service (Polish Act of 9 April 2010 on the Prison Service, 2010, par. 23) within the scope of revealing crimes and detecting their perpetrators is based on the principle of legalism (Polish Regulation of the Minister of Justice of 3 February, 2011) binding in the Polish criminal law and the resulting necessity to undertake activities by law enforcement bodies, whenever there is a justified suspicion that a crime has been committed. Prison officers may acquire a belief of such a suspicion, but they are not competent to carry out the necessary investigative or operational/exploratory work, and can only support police officers in these areas.

\section{Study assumptions}

The subject of the study is information obtained by officers in the prison environment. Taking into account the area of the penitentiary unit where they carry out their tasks and their nature. The aim of the research is the effectiveness of information extraction by prison officers, their procedures and the level of awareness of the importance of this issue in correlating life and health risks. The aim of the study is to determine the level of knowledge of how important an element in the security system of an individual is the acquisition of information and the possibilities of acquiring information itself. Also to identify the specific risks of underestimating this 
task and the techniques and situations that can be used. Through the study problems, knowledge was sought on the acquisition of information in the general sense of ensuring the security of a prison, detention centre and in the specific situational context appropriate to the service in the position held. The study adopted the methodological assumptions of Tadeusz Pilch and Teresa Bauman (Pilch, Bauman, 2011).

\section{Characteristics of the research sample}

The respondents are prison and remand officers from thirteen district inspectorates of the Prison Service (Białystok, Bydgoszcz, Gdańsk, Katowice, Koszalin, Kraków, Lublin, Olsztyn, Opole, Poznań, Rzeszów, Szczecin, Warsaw) out of the fifteen organised in Poland.

The study involved 50 officers of whom 15 were women and 35 were men. The gender disparity is related to the preponderance of men serving in the formation. 6690 women and 22193 men serve and work within the ranks of the Prison Service (Ministry of Justice, Central Management Board of the Prison Service, 2020). The majority - 49 of the 50 respondents - had a university degree, one a bachelor's degree. They serve in the security $(48 \%)$, quartermaster $(26 \%)$, penitentiary $(12 \%)$, health $(10 \%)$ and therapeutic $(4 \%)$ departments. All of them carry out tasks with inmates while on duty. The officers studied have between 1 and 16 years of service (14 people with up to 5 years of service, 23 people with between 5 and 10 years of service, 12 people with between 10 and 15 years of service, one person with more than 15 years of service) (Figure 4).

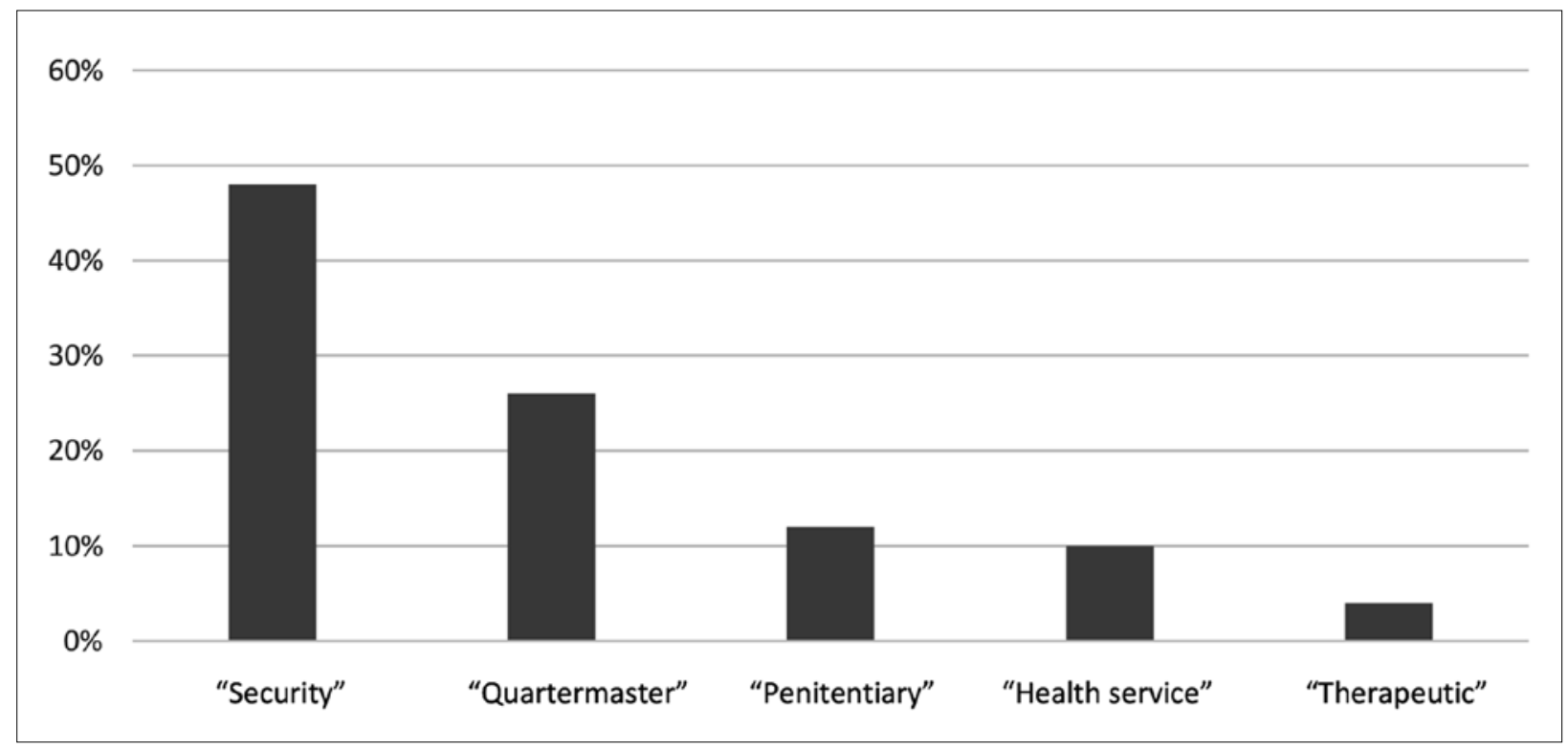

Figure 4. Departments of the service represented by study participants

Source: own elaboration

The officers studied are mostly experienced in their positions. They are lower and middle level staff. They do not hold management positions and do not hold officer ranks. They are mostly systematic in their service directly with persons deprived of their liberty. To a significant extent, their official tasks are reduced to carrying out day-to-day activities with inmates, in accordance with the specific nature of the department represented and the inherent security (Figure 5). 


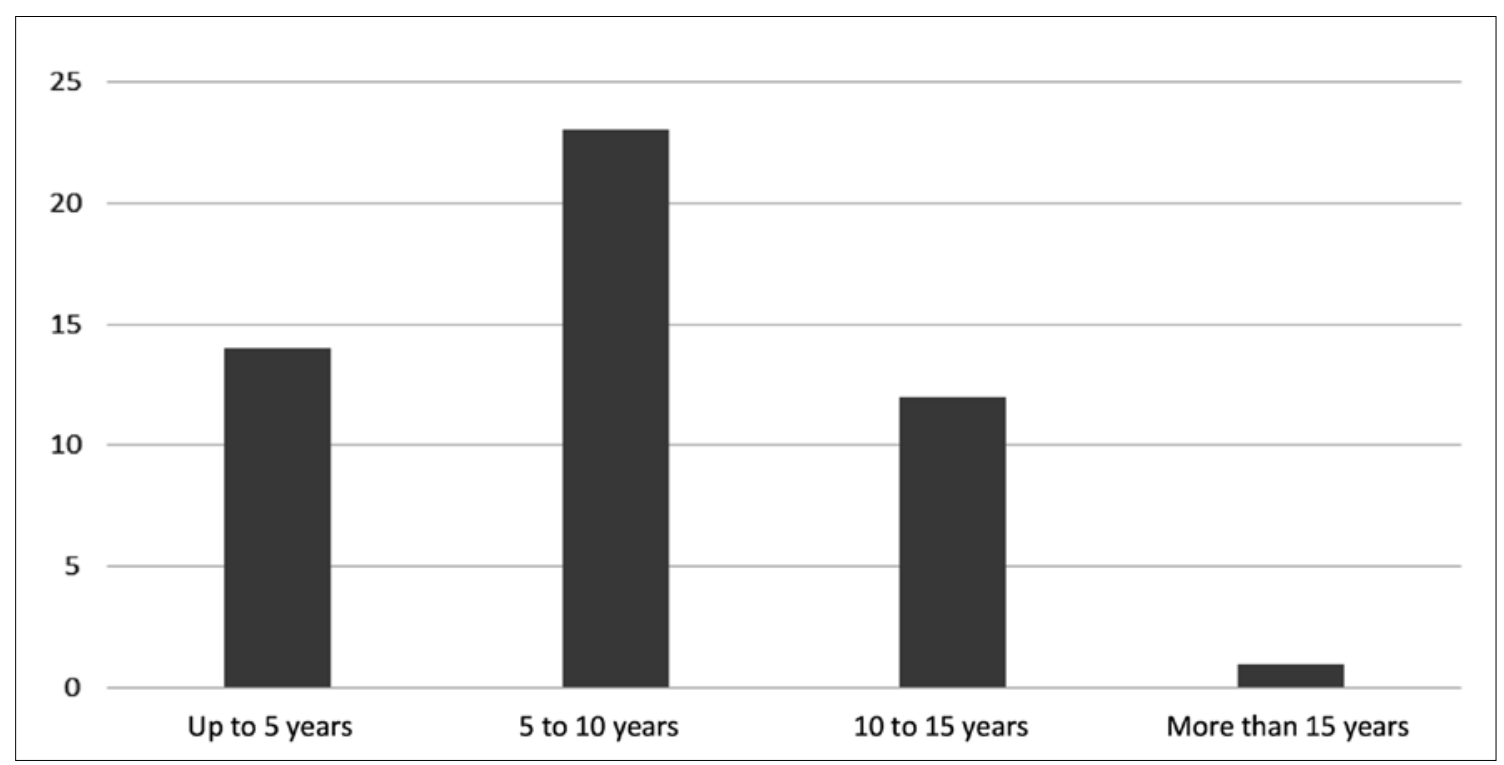

Figure 5. The seniority structure of study participants in the Prison Service.

Source: own elaboration

\section{Study method and description of the tool}

The diagnostic survey method was used to conduct the study. The study tool was a survey questionnaire. The first part of the questionnaire asked so-called metric questions. They concerned: the length of service in the Prison Service, department of formation, position held and rank held, in addition the region of Poland taking into account the organisational structure of the Prison Service, education and gender.

Further eight questions in the questionnaire addressed the officers' concerns and capabilities in relation to the study issue undertaken. These were mostly closed questions, with a choice of one or more options. Due to the complexity of the problem addressed, the author also allowed, in numerous cases, the respondents to complete an index of possible answers.

\section{Study results}

The following analysis allows, to some extent and in selected areas, to answer the questions posed about the effectiveness and ways in which the Prison Service officers acquire information relevant to security. The first question concerned the basic knowledge related to who is the competent person to obtain information within the penitentiary premises. The majority of respondents $-82 \%$ - gave the correct answer, i.e. "all officers and employees". One person stated that "officers appointed by the director of the unit", while three people considered that "only officers on duty in the penitentiary units". Five of the respondents incorrectly stated that these activities are carried out "only by security officers" (Order No. 23/18 of the Director General of the Prison Service, 2018, § 1, par. 5). In conclusion, it should be noted that $18 \%$ of the respondents had incorrect knowledge about who carried out preventive activities.

Another of the questions concerned their ability to obtain information themselves. More than half (58\%) of the respondents felt they had a high capacity in this area, $24 \%$ claimed low and $10 \%$ very high, while $6 \%$ found it difficult to say. One respondent felt that there were no options for this task (Figure 6). 


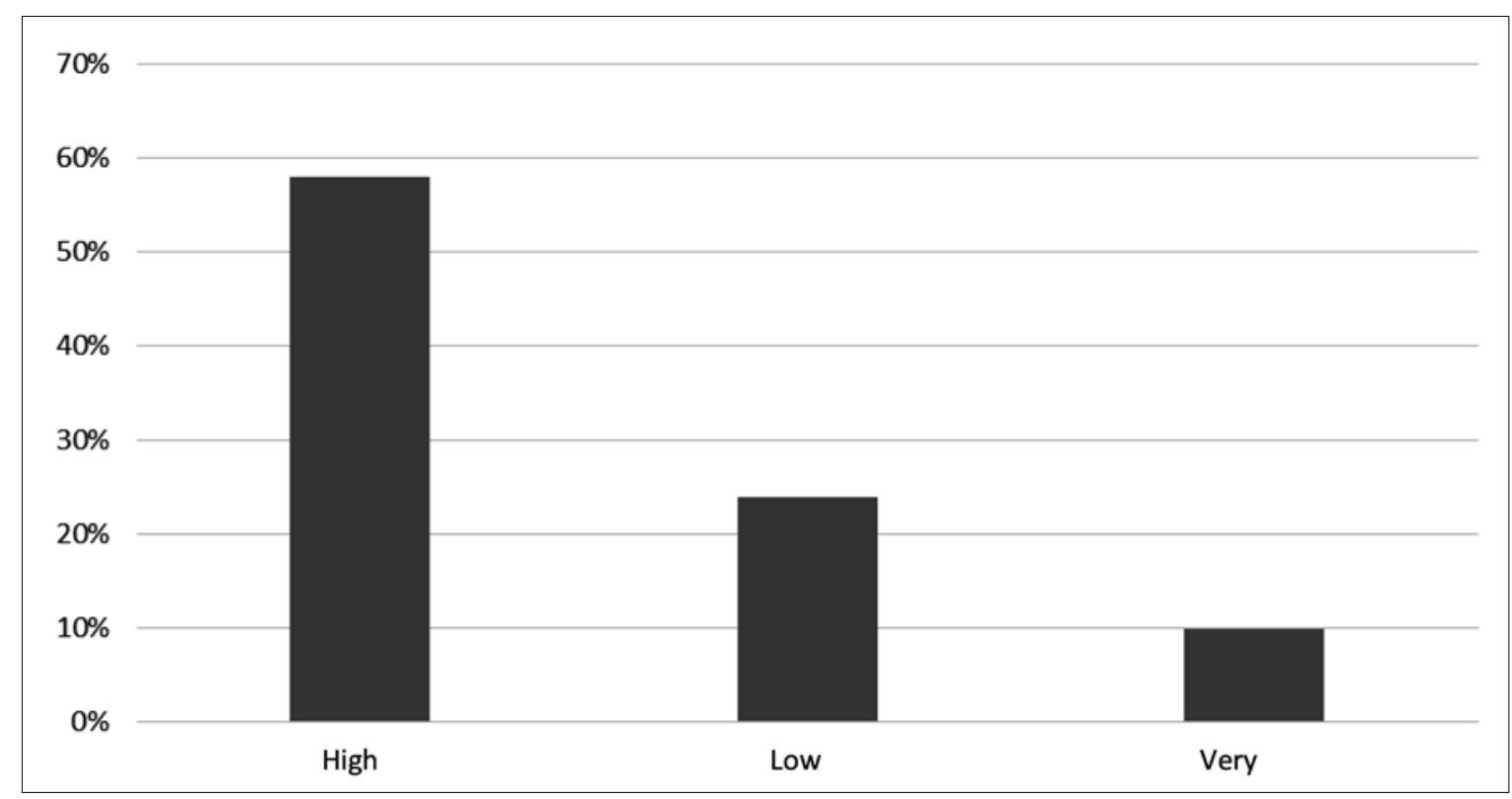

Figure 6. Assessing one's own abilities in obtaining information

Source: own elaboration

All respondents considered that a prison or detention centre is a place where security information should be obtained. A significant proportion, $78 \%$, also considered that obtaining information could be very important in this context, while $22 \%$ considered it very important. There was not a single person who considered that obtaining information was of little or no importance.

The next question asked for the identification of a specific situation, one or more, which could be prevented through acquired and properly used knowledge. Here, a sizeable proportion of respondents indicated more than one answer - 41 felt that "loss of life of an officer or inmate"; 44 that "loss of health of an officer or inmate"; 42 that "escape of an inmate"; also 42 that "smuggling of narcotics" could be prevented. In addition, some respondents suggested other situations including loss of health and life of persons outside the penitentiary unit; as well as mutiny (Order No. 24/14 of the Director General of the Prison Service, 2014).

Furthermore, the majority of respondents believe that information-gathering activities can prevent the most extreme and unwanted situations, such as the loss of life of an officer or prisoner - this is confirmed by $84 \%$ of respondents. Even more, $90 \%$, believe that this can translate into preventing the aforementioned people from losing their health.

On the other hand, when asked about the knowledge of which methods/techniques to use to obtain information, the majority (43) said they had such knowledge, 6 said it was difficult to say. One person considered that they had no knowledge of this topic. However, when analysing which techniques were indicated by the majority of people, it should be stated that those were observation and control of conversations. Individuals also pointed to checks carried out within the unit, analysis of records and inmates who share relevant information.

\section{Conclusions}

By analysing the results of the conducted studies, several conclusions can be drawn. First of all, officers of the Prison Service formations have a very high awareness of the legitimacy of activities in the form of acquiring information. All participants in the study confirmed this necessity as directly related to safety in the service area.

The vast majority of those surveyed say they know how to act after acquiring security-relevant information. However, this declaration was not verified in the research process. One person has no such knowledge, while 
two find it difficult to answer this question. Studies would need to be carried out on the behaviour of staff once they have obtained information. Thus, the effectiveness of its proper circulation should be verified.

Some respondents were not aware that obtaining information is the task of all officers and employees, indicating only selected ones as competent to perform this activity. It is therefore worth considering a training system that makes prison staff aware this task lies with everyone.

It is also worrying that only $58 \%$ of those surveyed consider that they have good opportunities to obtain information. This appears to be a low rate given the nature of the group studied, most of whom have direct contact with inmates. It should be noted that even the absence of direct contact also offers, in many cases, opportunities in this respect. This issue should also be taken into account when designing changes to the training system.

It must be stated that the awareness of prison staff of the importance of information in connection with security is high. However, the implementation of this task and its inclusion in the scope of own competences is not necessarily so high. The knowledge and possibilities of using the techniques comes down to the basic ones related to the observation or control of conversations. On the other hand - the easiest and most obvious ones. The lack of ability to name particular techniques may also have resulted in a failure to demonstrate them during the study. It can also be based on the assumption that most staff respond intuitively to specific information without necessarily having the ability to identify it accurately.

Taking into account the aforementioned dynamics of change, in the area of public safety (Kośmider, Strzelec, 2019), it must be stated that the frequency with which officers and employees participate in the training process remains extremely important. This is also important in the context of the ongoing phenomenon of extending the minimum period of service (Werbiński, 2020). Therefore, training in information retrieval should be cyclical (Kośmider, Strzelec, 2020).

During the survey, $52 \%$ of respondents were able to identify their own achievements related to information acquisition. This ratio shows that more than half of the staff have been more or less successful in this area this confirms that information gathering is an extremely important and real part of the way in which the prison unit is protected.

\section{References}

Bulenda, T., Rzepliński, A. (2019). Modernising prisons. 5th Penitentiary Congress. University of Warsaw, Institute of Social Prevention and Resocialisation, Central Board of Prison Service, Warsaw.

Czarkowski, J.J. (2019). Wykorzystanie metody obserwacji w penitencjarystyce. [The use of the observation method in penitentiary science]. The Prison Systems Review, 104, pp. 103-126.

Federal Bureau of Investigation. (n.d.). Retrieved January 12, 2021, from https://www.fbi.gov/image-repository/intelligence-cyclegraphic.jpg/image_view_fullscreen

Informacja - definicja, etapy obiegu informacji [Information - definition, stages of information preparation]. (n. d.). Strefa - Rozwój, Praca, Firma, Finanse, Dom [Zone - Development, Work, Company, Finance, Home]. https://flstrefa.pl/informacja.html

Kośmider, T., Strzelec, M. (2019). Rozważania nad problematyką bezpieczeństwa publicznego. Przeciwdziałanie zagrożeniom. Rola służb [Reflections on public safety issues. Countering threats. The role of services]. Wydawnictwo Instytutu Wymiaru Sprawiedliwości, Warsaw.

Kośmider, T. (2020). Szkolenie funkcjonariuszy Służby Więziennej w zakresie użycia środków przymusu bezpośredniego. Wprowadzenie do problematyki. [Training of the Prison Service officers in the use of means of direct coercion. Introduction to the issues]. Wydawnictwo Episteme, Warsaw.

Lewandowski, M. (2019). Zadania Służby Więziennej na rzecz bezpieczeństwa państwa — kierunki zmian. [Tasks of the Prison Service for national security - directions of change]. Wiedza Obronna, Towarzystwo wiedzy obronnej, Warsaw.

Lidel, K., Piasecka, P., Aleksandrowicz, T.R. (2012). Analiza informacji. Teoria i praktyka. [Information analysis. Theory and practice]. Difin, Warsaw. 
Lidel, K., Piasecka, P., Aleksandrowicz, T.R. (2013). Analiza informacji w zarzadzaniu bezpieczeństwem. Zarzadzanie bezpieczeństwem. [Information analysis in security management. Security management]. Difin, Warsaw.

Poklek, R. (2010). Instytucjonalne i psychospołeczne aspekty więzienia. [Institutional and psychosocial aspects of prison]. Centralny Ośrodek Szkolenia Służby Więziennej w Kaliszu, Kalisz.

Pilch, T., Bauman, T. (2011). Zasady badań pedagogicznych. Strategie ilościowe i jakościowe. [Principles of pedagogical research. Quantitative and qualitative strategies]. Wydawnictwo Akademickie ŻAK, Warsaw.

Werbiński, J. (2011). Git online. Forum Penitencjarne 8, Centralny Zarząd Służby Więziennej, Warsaw.

Werbiński, J. (2020). Rodzaje szkoleń realizowanych w Służbie Więziennej [Types of training provided in the Prison Service]. In: Kośmider, T. (Ed.). Szkolenie funkcjonariuszy Służby Więziennej w zakresie użycia środków przymusu bezpośredniego Wprowadzenie do problematyki [Training of Prison Service officers in the use of direct coercive measures Introduction to the issues]. Warsaw: Wydawnictwo Episteme.

Instruction of the Deputy Director General of the Prison Service. Letter O-073/90/12/1906 of 7 September 2012 concerning the unification of procedures related to the transmission, collection and processing of information obtained as a result of the implementation of preventive measures, Warsaw 2012.

Ministry of Justice, Central Management Board of the Prison Service. (2020). Annual Statistical Information for 2020. Warsaw: Ministry of Justice, Central Management Board of the Prison Service

Order No. 24/14 of the Director General of the Prison Service of 10 July 2014 on counteracting the entry of narcotic substances and their circulation in the territory of penal institutions and remand prisons.

Order No. 1/2018 of the Director General of the Prison Service of 03 January 2018 on duty service in organisational units of the Prison Service, incidents that may occur in the Prison Service and how to explain and document them.

Order No. 23/18 of the Director General of the Prison Service of 18 April 2018 on the creation and organisation of penitentiary units in prisons and remand centres.

Polish Act of 9 April 2010 on the Prison Service.

Polish Regulation of the Minister of Justice of 3 February 2011 on the procedure of cooperation between the Prison Service and the Police in the event of a threat to or breach of the security of an organisational unit of the Prison Service or convoy.

Polish Regulation of the Minister of Justice of 16 October 2016 on ways to protect organisational units of the Prison Service.

Jakub WERBIŃSKI - is the master of social sciences in the field of pedagogy. Since 2003, he has been an officer of the Prison Service - he started his service in the Correctional Facility in Sieradz, carrying out penitentiary and protective tasks. Since 2013, he has been involved in the training of officers of the Prison Service in the field of security - initially at the Central Training Center of the Prison Service in Kalisz - Protective Training Institute, currently at the Higher Justice School - Institute of Security Sciences, Laboratory of Protection and Defense of Organizational Units of the PS. He is the author of didactic materials, co-author of safety training programs, participated in many training and scientific projects, including international ones. In addition, he completed a number of courses, including related to the training of prison staff. In addition to conducting classes related to the security of penitentiary units, he is a researcher. Representing Security and Defense Workshops of Organizational Units of the Prison Service, he functions in the area of prison security. Recently, he has conducted research on information as an important factor influencing the safety of prisons and pre-trial detention centers.

ORCID ID: https://orcid.org/0000-0003-3740-3981

This work is licensed under the Creative Commons Attribution International License (CC BY) http://creativecommons.org/licenses/by/4.0/ 